\title{
Exploring Health Disparities in Indigenous Akit Tribal Community in Riau Province
}

\author{
${ }^{1}$ RD. SITI SOFRO SIDIQ, ${ }^{2}$ R. YOGIE PRAWIRA W, ${ }^{3}$ HINDINA MAULIDA, ${ }^{4} R$ WILLYA \\ ACHMAD W \\ ${ }^{1}$ Departement Sociology, Faculty of Social Science and Political Science, Universitas Riau, \\ Pekanbaru, Indonesia \\ ${ }^{2,3}$ Communication Science, Faculty of Social Science and Political Science, Universitas Tidar, \\ Indonesia \\ ${ }^{4}$ Faculty of Law, Universitas Islam Nusantara, Bandung, Indonesia \\ email: ${ }^{1}$ sitisofrosidiq@lecturer.unri.ac.id; ${ }^{2}$ yogieprawira@untidar.ac.id; ${ }^{3}$ hindina@untidar.ac.id; \\ ${ }^{4}$ radenwili@gmail.com
}

\begin{abstract}
Ten years have passed and there has been no result of an empowerment program for remote indigenous Akit tribal communities in Riau. The Akit tribe is an ancient native Malay tribe (Proto Melayu) in Riau Province. These indigenous people are still less fortunate in terms of health and social. This study investigates the root causes of health inequalities in the Akit community to get a complete picture of the problem. By using a qualitative approach and case study methods, this research is conducted by means of in-depth interviews, observation, and literature study. The results of the study show that the root cause of failed empowerment is a lack of synergy between government agencies, in which each agency had its own program, thus it poses disadvantages to the society where there are still illiterate sufferers, people who are heavily dependent on the underdeveloped environment that make them ill, and cultural institutions that are not feasible and binding to the social system that prevents people from developing.
\end{abstract}

Keywords: health disparities, indigenous community, Akit Tribe.

\section{Introduction}

Ten years was over and no result in the empowerment program for the Akit community in Riau. This indigenous tribe is still in socially disadvantaged conditions. This study investigated the root causes of health disparities in the Akit community to get full pictures of its problem. Akit community is one of the indigenous tribes in Riau province with poor health quality as seen from their house condition, sanitation, water quality, and health facilities. As a remote community, they have a similar right to health quality as expressed by (Gracey \& King, 2009) that the government needs to collect information on health needs and conditions and must allocate sufficient resources to meet the health of the original community thereby minimizing differences between indigenous and non-indigenous communities.

In view of the recognition of equal rights to health, articles 4 and 17 of Law no. 36 of 2009 describes equal rights to health and the right to fulfill the right to life and is legally recognized in the Indonesian government and even internationally, this is part of optimizing the empowerment of the lagging people (Sidiq \& Achmad, 2020). Efforts to improve conditions for indigenous peoples are targeted at remote areas, starting in 1972. Some areas have been successfully empowered, but some have failed, as happened to the Akit community in Kepau Baru village. The government has started empowerment efforts since 2005, but the community is still living in socially disadvantaged and poor health conditions.

United Nations Declaration on the Rights of Indigenous Peoples (UNDRIP) Article 21 , section 1 also recognizes the right to health for indigenous peoples as stated:

"Indigenous peoples have the

Received: July 06, 2020, Revision: October 20, 2020, Accepted: June 08, 2021

Print ISSN: 0215-8175; Online ISSN: 2303-2499. DOI: https://doi.org/10.29313/mimbar.v37i1.6366

Accredited Sinta 2 based on the decree No.10/E/KPT/2019 until 2024. Indexed by DOAJ, Sinta, Garuda, Crossreff, Dimensions 
right, without discrimination, to the improvement of their economic and social conditions, including, inter alia, in the areas of education, employment, vocational training and retraining, housing, sanitation, health, and social security."

United Nations Declaration on the Rights of Indigenous Peoples (UNDRIP) Article 24 describes the rights of communities over their traditional medicine as well as the preservation of the treatment practices that have become their culture without prejudice to access to health services, as follows:

"Indigenous peoples have the right to their traditional medicines and to maintain their health practices, including the conservation of their vital medicinal plants, animals, and minerals. Indigenous individuals also have the right to access, without any discrimination, to all social and health services."

Indonesian Law Regulations through Ministerial Regulation no. 65 year 2013 suggested that empowerment in the health sector must meet the following principles:

Respect the local, which includes local knowledge, local skills, local culture, local processes, and local resources.

Ecological principles, which include interconnection, diversity, balance, and sustainability.

The principles of social justice and human rights, which do not harm and always provide benefits to all parties.

Sustainability is a crucial concept in empowerment because it is a long-term activity that requires consistency and a journey that requires high spirits (Blanchard et al., 2001).

UNDRIP and Ministerial Regulation no. 65 the year 2013 stipulate that indigenous peoples have traditional treatments, and their treatment practices must be recognized for their rights. Traditional medicine is a practice designed to promote mental, physical, and spiritual health based on beliefs that existed before the dissemination of Western scientific treatment (Schiff \& Moore, 2006). Traditional medicine is also associated with the use of herbal medicine, along with ceremonies and rituals to achieve excellent mental health.

Traditional medicine is an integral part of indigenous health systems because people see that human health is so closely related to the earth as a source of life rather than a resource (Horse in Robbins \& Dewar, 2011). Traditional medicine is an attempt to cure diseases based on hereditary beliefs, either by using available natural ingredients that believed to have healing properties, or through an intermediary (shaman) who is recognized to have specific strengths in himself to eliminate the disease (Setyowati \& Wardah, 2007)

Perceptions about the concept of sickness, health, and its relation to the use of medicinal plants have traditionally formed through socialization from one generation to the next, and people believe it as the truth (Rahayu, 2006). For example, the knowledge of medicinal properties of a plant by the Dayak Benuaq is the result of long experiences and observations of the surrounding plants, such as the bitter plant to treat malaria. There is also a certain plant that is believed to have the efficacy to accelerate the recovery of maternal health conditions postpartum (Falah et al., 2013). This system is complex and comes from the experience of history and worldview. Indigenous peoples also have the value that health is a holistic concept consists of physical, mental, and spiritual aspects.

Based on this explanation, this study investigates the root causes of health disparities of the Akit community in order to explore their health behaviour, local wisdomrelated health, and empowerment program that has been given by the government. The results of research shall be recommended either to the local government or the central government through Ministry or Social Department of remote indigenous community empowerment that can be as a reference for designing policy or new empowerment strategy.

Furthermore, this study elaborates the legal and policy framework, general profile of the Akit community, and the root causes of human infringements. The conclusion is given in the last part of this article, followed by some recommendations for the stakeholders related.

\section{Research Methodology}

A qualitative method with a case study approach is used in this research to focus intensively on one particular object to obtain 
an overview of the case. A good case study according to (Anggito \& Setiawan, 2018) is to be carried out directly in the actual life of the case being investigated.

The data collection technique was carried out by in-depth interviews with the Ministry of Social Affairs of the Republic of Indonesia, the Head of the Riau Province Social Service, the Manager of the Riau Province Customary Agency, traditional leaders of the Akit tribe, and the Akit Community. Observations were made in the research area in Kepau Baru Village and community activities related to health aspects. In addition, related documents such as meeting notes, statistical data, previous research and other research on similar topics were used to supplement the data. The data collected in this study were analyzed in stages, namely organizing the data, reading complete information and coding, making detailed descriptions of the cases and their contexts, and drawing a conclusion.

\section{Result and Discussion Result}

\section{General Profile of Akit Community}

Riau Province has six indigenous tribes, namely Bonai tribe, Talang Mamak Tribe, Sakai Tribe, Hutan Tribe, Duano Tribe, and Akit Tribe. The Akit tribe originated from the Old Malay Tribe (Proto-Melayu), who came through the Malacca Peninsula (Malaysia) on the Vedoit race migration from Srilanka and India at the end before the ice age (Hamidy, 1991). The area that became the initial entry of this tribe in Riau Province is Rupat Island in Bengkalis Regency, which is then followed by the arrival of other tribes.

The word Akit comes from rakik or raft, which means a means of water transportation. The term is inspired by the tribal way of life in the waters, seas and river estuaries rather than earning a living by hunting and gathering. Historically, there are three kinds of Akit tribes, namely the Akit Biasa or ordinary Akit (the tribe that meets the river), the Akit Ratas (the tribe that walks on the river path), the Akit Hutan (the tribe that divides the forest). The Akit people in Riau Province currently live in forests and beaches or rivers with more varied livelihoods.

Akit community spread in Pelalawan District, Penyaley Island, Bengkalis Regency,
Siak Regency, and Meranti Islands Regency, where the area is closed to the border of Malaysia State. As a village adjacent to the border of another country, the Kepau Baru village is far away from Riau province, which is about $346 \mathrm{~km}$ that needs more than a day trip, with limited transportation modes and alternated.

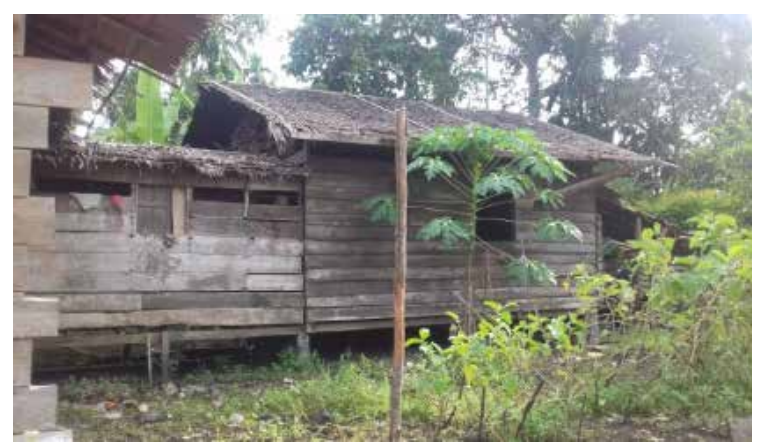

Figure 1: Akit Tribe House

Source: Akit Tribe, 2018

Figure 1 is the original house of the Akit tribe; the scattered pattern of their settlement shows the deteriorating health quality of the Akit community. The distance of each house is quite far, about one kilometer that is only connected by footpaths. The position of the house is messy and not strategically to the road. The size of the house is mostly $4 \times 5$ meters, with the height is approximately 2.5 meters. It completes with wallboard and nipa palm as its roof, but no separation between rooms. The other side of the room serves as a multipurpose room that is also used as a kitchen. The kitchen appliances are also still inadequate and straightforward.

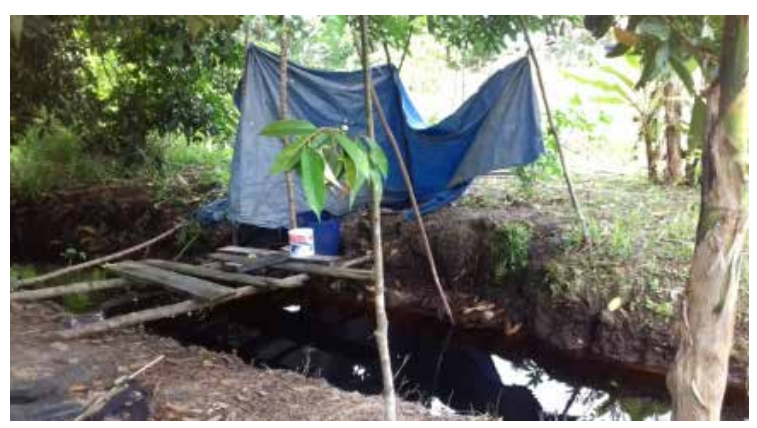

Figure 2: Akit Tribe Community Toilet

Source: Akit Tribe, 2018

The conditions illustrate (in the figure 2) that the Akit community does not have proper toilets. The toilet is still very simple, covered with leaves and a well. For bathing, washing clothes and dishes, the Akit tribe uses a flowing river. Unfortunately, the river flow is not smooth and has brown water. 
The people's habit is to shower without using soap and not brushing their teeth. They are familiar with soap, toothpaste and toothbrushes, but they do not understand the importance of oral and dental hygiene, apart from their limited supply. The village has only a few shops selling daily necessities due to the long distance and the economic inability to buy health related products. As an alternative, they eat betel and areca leaves.

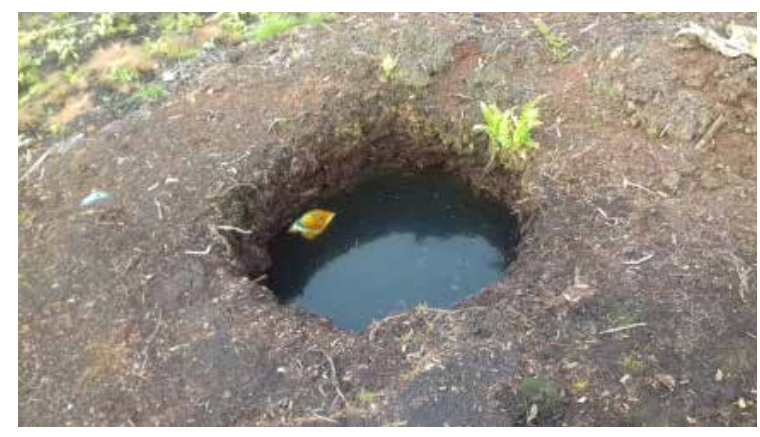

Figure 3: Source of drinking water

\section{Source: Akit Tribe, 2018}

Figure 3 shows the main water source for the community and it is another health problem. The minimum availability of clean water sources for drinking and bathing consumption for the Akit tribe community has resulted in frequent skin diseases. The source of drinking water comes from dug wells with a depth of 1-1.5 meters and a diameter of 1 meter. Wells conditions are very poor since they don't bordered by boards or walls. The water is consumed along with woody roots and leaves on the surrounding wells. It is also consumed without being cooked beforehand.

The attachment of hereditary values to the Akit community causes them to have a strong belief in Monti (older people with expert knowledge of traditional health treatment). Mostly, the treatment for sick people depends on the traditional treatment using plants accompanied by certain spells. The disease that people often suffered is stomachache and toothache. In pursuit of healing, they usually prioritize healing rituals led by Monti (shaman). If the Monti fails, the sick person is taken to the village health centre by referral from Monti. The condition of the sick people mostly is getting worse, and frequently some sick people eventually died. The process of giving birth is also helped by Monti with minimum equipment.

The health problems faced by the sick are caused by geographic conditions that are difficult to access health facilities. This is in accordance with the results of the research by (Situmorang, 2019) that basic service facilities such as health in remote indigenous communities are very apprehensive and there need to be special efforts from the government to provide intervention. A health facility is not spread evenly in all sub-villages, but only in the centre of the village. The health facilities existed are three centres of integrated family planning and health service and one health centre in the village with inadequate equipment and drug medicine availability. Akit people who live far away from the village centre must take a walk nearly $4 \mathrm{~km}$ to reach it, and even the residents who live in the sub-village must walk for $8 \mathrm{~km}$. Medical personnel in the village is only one nurse. It is not comparable with the number of Akit community residents.

These constraints cause on limited and uneven health service to the community, for instance, mothers who participated in family planning in less than a half, also infants who get immunization of Bacillus CalmetteGuérin (BCG), Diphtheria, Pertussis, and Tetanus(DPT), polio, and measles are only about 28 babies. In addition to geographical problems, traditional cultural perception of treatment, the availability of adequate health facilities, the affordability of the use of health facilities also become an obstacle for the Akit community to take advantage of such facilities since they are in poor condition and have low income.

\section{Root Causes of Human Rights Infringements}

The main goal of health development is to create a smooth, affordable, and better degree of public health for all society. The government has implemented various efforts to improve the degree of public health through empowerment programs, but the results are not in line with the expected target. Based on the results of research in Kepau Baru village, there are four root causes of the empowerment program failure related to health problems.

\section{Incongruity among Governmental Institutions.}

Health as a human right has been recognized both in the world and in Indonesia, but a reasonable degree of health can not be enjoyed by everyone as happened in indigenous communities in Indonesia. The Government of Indonesia through Law No. 36 year 2009 on health in section 50 
has stipulated that "the Government and regional governments are responsible for improving and developing health efforts." The article affirms that the improvement and development of health efforts to achieve good quality health for communities require inter-governmental cooperation and intersectoral cross-cutting. In other words, health efforts are not only the responsibility of the central government, the ministry of health, but also the responsibility of the local government and its apparatuses, and other related ministries.

It is a responsibility of of all parties to empower the public health sector, primarily indigenous peoples listed in the Regulation of the Minister of Health of the Republic of Indonesia No. 65 Year 2013, Chapter III on Direction and Strategy for Implementation and Development of Community Empowerment in the Field of Health stating "Promoting partnership and cross-sectoral participation related, private sector, business world and stakeholders in developing and fostering community health empowerment." The regulation of cross-sectoral partnerships in the effort of health empowerment should become a strong foundation for the relevant government institutions to work together to create a safe and influential community in the health sector.

In reality, however, there is no cooperation between one institution and the other as expressed by the Head of Social Service of Riau Province below:

"The appropriate empowerment has been conducted in this village and this is not the first time ... we from social service department have done it more than once with different achievement targets ... one of them is health. However,.. we can not give the maximum results because health problem is actually not under our authority.. It is (belong to) special division, that is the health ministry. Our duty, according to the rules, is only mapping, identifying, and providing recommendations on the things that need to be empowered and upgraded, including health... "

Furthermore, the Head of Social Service Department of Riau Province stated that they have invited the Health Ministry of Riau Province team during the focus group discussion at the provincial level as well as in the seminar of the preliminary study of empowerment preparation. Sometimes, however, the relevant institutions do not come, or they send people who are not competent (have no access for policy making) to the meeting. Thus, their presence do not contribute significantly or are merely a formality.

"...We did invited them.. we always invite the health department, not only the health department but also other related institution such as the environmental protection department.. but $\mathrm{mm}$.. they do not come, only the staff members do ... so it is useless ... and we decided to have selfempowerment and relying on existing resources for health problems "

The document of the Poverty Reduction Strategy in Surakarta revealed incoherence between institutions in the empowerment process. The document notes that there are some problems and challenges in handling poverty, such as the unsynchronized implementation of activities between each sector and weak coordination of each Local Government Work Unit (SKPD) when compiling poverty interventions.

The lack of cross-sectoral synergies in policy implementation and development processes is also recognized by (Swandaru, 2016). The estuary of constraints in solving such problem is due to the lack of synergy among the related ministries. Synergy means building and ensuring a productive internal partnership relationship as well as a harmonious partnership to produce useful and quality work. Synergistic and constructive relationships will occur when there is an understanding of the optimal and potential resources of each of the actors (agents) of the development based on awareness and mutual agreement on the vision to be achieved in public service (Suharyanto, 2005).

The importance of synergy among agencies in the empowerment process has been proposed by (Keban, 2007):

"The improvement of welfare and empowerment requires cooperation not only between sectors but also regions, which in various literature known as policy network and intergovernmental management."

Synergy can make not only the empowerment more active and get the right target, but also can avoid the overlapping 
program between institutions that can trigger the happening conflict. Several studies on the empowerment of isolated tribes in the health sector also recommend cross-sectoral cooperation in government institutions (Chanan, 2011; Pulver et al., 2010; Sidiq, Rd. Siti Sofro, Jalil, A \& Achmad, 2021 ; Sopandi, 2010.).

\section{The Education of Akit Community}

Health is an essential thing in human life, both physical and spiritual. Currently, the health degree of remote areas in Indonesia is in poor condition. According to Blum (Nasution, 2004), four factors that affect the health status of public health or individual, i.e., environment, heredity, health service, and people's behaviour. There are two kinds of behavior: overt behaviour and covert behaviour. Covert behaviour refers to the knowledge and attitudes of a person to an object, whereas overt behaviour is an action.

In remote areas, the majority of people's knowledge to behave healthily is very poor, which causes lousy health status. Several solutions could be taken, such as implementing a healthy lifestyle, maintaining the cleanliness of the environment, increasing knowledge about health through education, and improve the quality of health services. Giving knowledge about health through education is crucial because the primary way to have health behavior is from the knowledge obtained.

However, many people are not aware of the importance of education to achieve prosperous health. They do not consider that to find out information about a disease, environmental preservation, and application of a healthy lifestyle is based on education. Fred in his research concludes that less knowledge and information access causes a person to have inadequate knowledge about the dangers of unhealthy behaviour and lack of willingness to adopt healthy behaviours (Pampel et al., 2010).

Akit community has problem of backwardness in education. Based on data from the Indonesia Statistic Centre, the majority of population does not complete elementary school. Approximately, 382 people only graduated from elementary school, and more than 400 people do not take any education or illiterate. It happened due to three main points: uneducated parents who do not have motivation and concern for children's education; the distance between residence and the school is about 4-8 $\mathrm{km}$ that becomes an obstacle for children to go to school by walk; and limited educational facilities in the form of buildings and teachers. There are two kindergartens, one elementary school, and one junior high school in Kepau Baru Village. The number of teachers is only seven people in which this teacher taught them alternately, such as morning in elementary school and afternoon in junior high school.

Another fact found is that some parents forbid their children to go to school because of the long distances, as happened in the sub-village:

"... I do not allow my kids to go to school because of its long-distance. They have to walk $8 \mathrm{~km}$ from here. I do not have time to drove (read: picked) them because I have to work). If I do not work, I can not get money to eat. So, better, I just let them play or help me... "

Teachers, in another point, also cannot provide solutions because of the distance and limited human resources. Teachers cannot come to the sub-village. In contrast to what happens to children who are away from school, children who live closer to school (about $4 \mathrm{~km}$ ) prefer to play outdoors, or in the rivers. Teachers cannot take the children back to class because of the limited number of teachers compared to the number of pupils.

Based on the previous explanation, It is impossible to let these people think of health if their knowledge is only at the elementary level. They also do not think about the benefits they will get from having decent education. Since health is related to education, the broader knowledge of a person in education will result in more health knowledge he obtained and more concerned in taking care of his health and others'. Ross and Mirowsky in their study explained that there is a correlation between the length of education and health consistency. School duration help learners develop a productive life capacity that will significantly influence health aspect, including full-time work, improving welfare, economics, self-control, more social support, and healthy lifestyle (Ross \& Mirowsky, 1999)

The above statement refers to the human capital theory; while status attainment model stated that schools 
provide general skills, particularly cognitive, specific skills that are useful for work, social values, behaviour and have a vital disposition in achieving goals (Lui et al., 2014). Higher education educates someone to logically and rationally thinking of specific issues from various perspectives in order to get better analysis and solutions. Besides, higher education improves the cognitive skills needed to be able to continue studying beyond school (Laflamme et al., 2004).

Seeman-Lewis's research and Seeman-Budros's research also concluded that people who know more about health are more able to initiate preventative behaviour (Freudenberg \& Ruglis, 2007). Knowledge gained can come from both formal and informal education. Various studies show that education is protection for health. In rich countries, the addition of one year of education can reduce mortality by about 8 percent (Pampel et al., 2010). Freudenberg added that policies to prevent dropping out and improving educational achievements have a significant impact on the health of the population (Freudenberg \& Ruglis, 2007).

The findings of Machenbach and Bakkers supported the previous claim by researchers who wrote about several comprehensive strategies in European countries to reduce health inequality (Mackenbach \& Bakker, 2003). They argue that EU, UK, Netherlands, and Sweden have made significant progress in health development throughout the population by introducing a comprehensive package of policies and interventions.

The emphasis of the package mainly focuses on handling factors of education, employment, and income. The research conducted by Pradono \& Sulistyowati (2014) also has a similar result that there is a correlation between education and health condition. The research findings stated that there is a significant affirmative mutual relation between health condition and knowledge as seen from the percentage of environmental health $(51,6 \%)$, healthy life behaviour $(48.2 \%)$, and educational level (47.1\%).

\section{Environmental Dependency of Akit People}

The health services in border areas have specific characteristics due to its geographical condition. On the one hand, the characteristic of a low level of community access to primary health care is caused by high-cost transportation, and the limited number of health personnel, drugs, and infrastructure facilities. On the other hand, indigenous peoples prefer the traditional treatment of plants that depend on nature.

The knowledge of plants used for traditional medicine transmits through a closed inheritance system in the family (Hariyadi, 2011 and Noorcahyati \& Arifin, 2012), done orally, and undocumented (Noorcahyati \& Arifin, 2012 and Setyowati \& Wardah, 2007). It results in the difficulties and degradation of traditional treatment knowledge development because the acceptance of each person will be different in the transfer process (Falah et al., 2013).

Medicinal plants are all plant species known and trusted to have medicinal properties and used as raw materials in traditional medicine (Zuhud \& Haryanto, 1994). Based on interviews with Monti and Akit community residents, the part of the plant used are leaves, roots, stems, water roots, stem water, bark, wood terraces, fruit, flowers, fruit peels, and sap. However, the most widely used part of medicinal plants is the leaves. This finding is similar to the use of medicinal plants conducted by the Malay Tribe around Bukit Tigapuluh National Park (Qomar et al., 2006). People use the leaf as part of traditional healing because they do not want to destruct the existing plant and in order to get the easiness aspect either in terms of taking or compounding herbs (Fakhrozi, 2009)

The Akit Tribe uses medicinal plants in several ways depending on the type of disease treatment, such as directly eaten or drunk, pasted, dripped, rubbed, scrubbed to the whole body, or used for bathing. Some medicinal materials also need to be heated, boiled, or softened first. The Akit Tribe believes that this natural herb can cure the illness better than medication by doctors, besides the traditional medicine is accessible and affordable. The tribe also believes that earth provides natural herb for all diseases in the form of plants around them.

\section{Ancestor Values}

The durable ancestral healing treatment of Akit Tribe community using traditional medicine based on tradition shows that people still keep the ancestral value passed down from generation to generation. The firm belief and compliance of the Akit tribe people to the treatment of Monti result in 
the difficulty of medical personnel to provide health service. For example, when people perform non-medical treatment ritual, there is a taboo that patients should stay at the house and are not allowed to meet other people.

\begin{abstract}
«I have seen a toddler's death because of fever, dehydration, and vomiting. I have advised them to go to health care immediately, and they told me to get the approval of the Monti who treated the toddler because for three consecutive days the toddler should not leave the house, so .. despite being told, they "had been forced" to did it. I try to communicate with the village head too, but there must be Monti's consent and it is useless... in the emergency condition it also needs Monti's consent."
\end{abstract}

A strong influence of Monti has caused Akit people to use their medical treatment continuously. It causes the assumption that Monti has multiple competencies to do both physical and 'supernatural' treatments. The community believes that the state of illness can be caused by the disorder of evil spirits so that spells do the treatment. Besides, people also believe that Monti acts as the community's stronghold to fight the evil interference.

«If the Monti is being abolished, then the community will be punished."

A late-diagnosed on the illness and less medical efforts, health service that causes more complex illnesses, expensive health cost, and a negative image on medical personnel because of their failure leading to deaths cause people of Akit tribe to trust the Monti. However, to gain support from the public, traditional healing and ancestor value need to be considered as revealed by Tsey et al., (2010) "to obtain the support of the indigenous community, the government needs to adopt the local health culture collaborating with the spiritual aspect exist in the community."

\section{Conclusions}

The health of the Akit tribe is still at a low level, although it has gained prior empowerment. It is due to the lack of synergy among government institutions, inadequate education, the environmental dependency, and the guidelines of the ancestors on health. Our recommendation towards such a phenomenon is that the Indonesian government with other ministries should actively participate in synergizing each institution of provincial and local government. Second, education for indigenous communities should conduct outside the classroom with the material concerning their local wisdom. Third, the empowerment team and stakeholders can create living pharmacies as a form of preservation for traditional medicine and knowledge. The last one is that medical personnel can collaborate with Monti, such as accompanying childbirth assisted by Monti.

\section{Acknowledgment}

We would like to show our gratitude to Raoul Wallenberg Institute for the support and assistance during the Regional Human Rights Research Initiative and Radu Mares for comments that greatly improved the manuscript.

\section{References}

Anggito, A., \& Setiawan, J. (2018). Metodologi penelitian kualitatif. CV Jejak (Jejak Publisher).

Blanchard, K., Carlos, J. P., \& Randolph, A. (2001). Empowerment Takes More Than a Minute (Second Edi). San Fransisco: Berrett-Koehler Publishers, Inc.

Chanan, M. (2011). Perlindungan Taman Wisata Alam Gunung Baung Pasuruan Jawa Timur. 6, 101-112.

Fakhrozi, I. (2009). Etnobotani Masyarakat Suku Melayu Tradisional Di Sekitar Taman Nasional Bukit Tigapuluh: Studi Kasus Di Desa Rantau Langsat, Kec. Batang Gangsal, Kab. Indragiri Hulu, Provinsi Riau [Institut Pertanian Bogor]. https://repository.ipb.ac.id/jspui/ bitstream/123456789/20745/1/E09ifa. pdf

Falah, F., Sayektiningsih, T., \& Noorcahyati, N. (2013). Keragaman Jenis Dan Pemanfaatan Tumbuhan Berkhasiat Obat Oleh Masyarakat Sekitar Hutan Lindung Gunung Beratus, Kalimantan Timur. Jurnal Penelitian Hutan Dan Konservasi Alam, 10(1), 1-18. https:// doi.org/10.20886/jphka.2013.10.1.1-18

Freudenberg, N., \& Ruglis, J. (2007). Reframing school dropout as a public health issue. Preventing Chronic Disease, 4(4).

Gracey, M., \& King, M. (2009). Indigenous health part 1: determinants and disease patterns. The Lancet (Vol. 374, 
Issue 9683, pp. 65-75). https://doi. org/10.1016/S0140-6736(09)60914-4

Hamidy, U. (1991). Masyarakat dan Kebudayaan di Daerah Riau. Pekanbaru: Universitas Islam Riau.

Hariyadi, B. (2011). Obat Rajo Obat Ditawar : Tumbuhan Obat dan Pengobatan Tradisional Masyarakat Serampas Jambi. Biospecies, 4(2), 29-35. https:// online-journal.unja.ac.id/biospecies/ article/view/524/439

Keban, Y. T. (2007). Kerjasama Antar Pemerintah Daerah Dalam Era Otonomi: Isu Strategis, Bentuk, dan Prinsip. Jurnal Ilmu Pemerintahan Indonesia, 11.

Laflamme, L., Engström, K., Möller, J., \& Hallqvist, J. (2004). Is perceived failure in school performance a trigger of physical injury? A case-crossover study of children in Stockholm County. Journal of Epidemiology and Community Health. https://doi.org/10.1136/ jech.2003.009852

Lui, C. K., Chung, P. J., Wallace, S. P., \& Aneshensel, C. S. (2014). Social Status Attainment During the Transition to Adulthood. Journal of Youth and Adolescence, 43(7), 1134-1150. https:// doi.org/10.1007/s10964-013-0030-6

Mackenbach, J. P., \& Bakker, M. J. (2003). Tackling socioeconomic inequalities in health: Analysis of European experiences. Lancet. https://doi.org/10.1016/S01406736(03)14639-9

Nasution, S. K. (2004). Meningkatkan Status Kesehatan Melalui Pendidikan Kesehatan dan Penerapan Pola Hidup Sehat. Seminar, November 1999, 1-7.

Noorcahyati, \& Arifin, Z. (2012). Etnobotani Tumbuhan Berkhasiat Obat Etnis Dayak Meratus Loksado Kalimantan Selatan dan Upaya Konservasi di KHDTK Samboja. Saudi Med J, 33, 3-8. https://doi. org/10.1073/pnas.0703993104

Pampel, F. C., Krueger, P. M., \& Denney, J. T. (2010). Socioeconomic Disparities in Health Behaviors. Annual Review of Sociology. https://doi.org/10.1146/ annurev.soc.012809.102529

Pradono, J., \& Sulistyowati, N. (2014). Hubungan antara Tingkat Pendidikan Pengetahuan tentang Kesehatan Lingkungan, Perilaku Hidup Sehat dengan Status Kesehatan Studi Korelasi pada Penduduk Umur 10 - 24 Tahun di Jakarta Pusat. Buletin Penelitian Sistem Kesehatan, 17(1), 89-95.

Pulver, L., Haswell, M., Ring, I., Waldon, J., Clark, W., Whetung, V., Kinnon, D.,
Graham, C., Chino, M., LaVelley, J., \& Sadana, R. (2010). Indigenous HealthAustralia, Canada, Aotearoa New Zealand and the United States-Laying claim to a future that embraces health for us all. World Health ..., 1-106.

Qomar, N., Setyawatiningsih, R., \& Hamzah Z. (2006). Karakteristik habitat mikro Salo (Johannesteijsmannia altifrons) di sekitar Taman Nasional Bukit Tigapuluh, Kabupaten Indragiri Hulu, Provinsi Riau. J. Natur Indones, 8-100.

Rahayu, M. (2006). Traditional use of medicinal herbs by local community of Wawonii island, Southeast Sulawesi. Biodiversitas, Journal of Biological Diversity, 7(3), 245-250. https://doi. org/10.13057/biodiv/d070310

Robbins, J. A., \& Dewar, J. (2011). Traditional Indigenous Approaches to Healing and the modern welfare of Traditional Knowledge, Spirituality and Lands: A critical reflection on practices and policies taken from the Canadian Indigenous Example. International Indigenous Policy Journal, 2(4). https://doi.org/10.18584/ iipj.2011.2.4.2

Ross, C. E., \& Mirowsky, J. (1999). Refining the association between education and health: The effects of quantity, credential, and selectivity. Demography. https://doi. org/10.2307/2648083

Schiff, J. W., \& Moore, K. (2006). The impact of the sweat lodge ceremony on dimensions of well-being. American Indian and Alaska Native Mental Health Research, 13(3), 48-69. https://doi. org/10.5820/aian.1303.2006.48

Setyowati, F. M., \& Wardah. (2007). Keanekaragaman Tumbuhan Obat Masyarakat Talang Mamak di Sekitar Taman Nasional Bukit Tigapuluh. Biodiversitas, 8(3), 228-232.

Sopandi, A. (2010). Strategi Dan Kebijakan Pemberdayaan Masyarakat Di Kabupaten Bekasi.

Suharyanto, H. (2005). Administrasi Publik, Entrepreneurship, Kemitraan, dan Reinventing Goverment. Yogyakarta: Media Wacana.

Sidiq, R. S. S., \& Achmad, R. W. W. (2020). Gender aspects in remote indigenous community empowerment program in Indonesia. Journal of Advanced Research in Dynamical and Control Systems, 12(6), 2104-2109. https://doi.org/10.5373/ JARDCS/V12I6/S20201172.

Sidiq, Rd. Siti Sofro, Jalil, A \& Achmad, R. (2021). Virtual World Solidarity: 
How Social Solidarity is Built on the Crowdfunding Platform Kitabisa. com. 18(1), 192-202. https://doi. org/10.14704/WEB/V18I1/WEB18083

Situmorang, R., Trilaksono, T., \& Japutra, A. (2019). Friend or Foe? The complex relationship between indigenous people and policymakers regarding rural tourism in Indonesia. Journal of Hospitality and Tourism Management, 39, 20-29.

Swandaru, R. B. (2016). Sinergi antar Kementerian dan instansi pemerintah sebagai terobosan dalam pengembangan panasbumi mencapai $7000 \mathrm{MW}$ di tahun PDF Free Download. http:// docplayer.info/29724714-Sinergiantar-kementerian-dan-instansipemerintah-sebagai-terobosan-dalam- pengembangan-panasbumi-mencapai7000-mw-di-tahun-2025.html

Tsey, K., Whiteside, M., Haswell-Elkins, M., Bainbridge, R., Cadet-James, Y., \& Wilson, A. (2010). Empowerment and Indigenous Australian health: A synthesis of findings from family well-being formative research. Health and Social Care in the Community. https://doi.org/10.1111/ j.1365-2524.2009.00885.x

Zuhud, E. A. M., \& Haryanto. (1994). Pelestarian Pemanfaatan Keanekaragaman Tumbuhan Obat Hutan Tropika Indonesia. Kerjasama Jurusan Konservasi Sumberdaya Hutan, Fakultas Kehutanan IPB dan Lembaga Alam Tropika Indonesia (LATIN). 